\title{
Tymoteusz Zydroń
}

dr inż.

Uniwersytet Rolniczy w Krakowie, Katedra Inżynierii Wodnej i Geotechniki

t.zydron@ur.krakow.pl

\section{Małgorzata Wojciechowska-Dymańska}

mgr inż.

absolwentka Uniwersytetu

Rolniczego w Krakowie

\section{Andrzej T. Gruchot}

dr inż.

Uniwersytet Rolniczy w Krakowie, Katedra Inżynierii Wodnej i Geotechniki rmgrucho@cyf-kr.edu.pl

\section{Tomasz Zaleski}

dr hab. inż.

Uniwersytet Rolniczy w Krakowie,

Katedra Gleboznawstwa i Ochrony Gleb

t.zaleski@ur.krakow.pl

DOI: 10.35117/A_ENG_17_05_02

\section{Influence of moisture content of cohesive soils on their shear strength}

\begin{abstract}
Influence of moisture content of two cohesive soils on their shear strength was the purpose of the tests. The shear strength tests were carried out in a standard direct shear apparatus of dimensions of the box $6 \times 6 \times 1,8 \mathrm{~cm}$. Each sample of assumed moisture content was preliminary compacted at Proctor apparatus, then was cut using a square cutter and to set into the shear box. Each series of samples were tested at four values of moisture content: equal, lower and higher than optimum moisture content. One series of samples, sheared at moisture content higher than optimum moisture content, the shearbox during consolidation and shearing was filled with the water to the level corresponding to shearing plane. Main tests were done using shearing rate equal to $1,0 \mathrm{~mm}$.min- 1 and time of consolidation was equal to 12 hours. Additional tests were done using shearing rate equal to $0,05 \mathrm{~mm}$.min- 1 and the samples during consolidation and shearing were saturated. Test results revealed that the most beneficial values of shear strength were obtained at optimum moisture content or lower that optimum moisture content. It stated that the increase of moisture content cause decrease of angle of internal friction and the highest values of cohesion was obtained at optimum moisture content. Comparison of test results obtained for series of samples sheared at optimum moisture content revealed that saturation of soil sample and low shearing rate cause very significant reduction of obtained values of cohesion.
\end{abstract}

Keywords: Cohesive soils; Moisture content; Shear strength; 


\section{Introduction}

The use of land in the construction industry as a construction material requires knowledge of their geotechnical properties, and in particular the shear strength. The values of the internal friction angle and cohesion depend on the degree of humidity and porosity of the soil. Therefore, in order to obtain the best possible durability parameters, it is required that in earth constructions the soil is densified with humidity close to the optimum [12], [7].

Typical work on the determination of shear strength parameters is based on the study of soils of natural or optimum humidity. Normally, the samples are shaved without failure and at high shear rates. On the other hand, the standard [10] recommends conducting tests on the failure of samples during consolidation and shear at the velocity determined by the consolidation of samples.

The aim of the study was to determine the influence of humidity on the shear strength of selected cohesive soils of different cohesion. In addition, the influence of shear surface roughness and shear rate on the shear strength parameters was determined.

\section{Scope and methodology of research}

The study was conducted for two cohesive soils with different content of clay fraction. These were: smallpox - sandy dust from the surface landslide area on the Bochnia bypass (Malopolskie province) and medium cohesion - sandy loam from the north-western part of Krakow, which is the basis of the local road.

The basic physical properties and parameters of soil compaction were determined by standard methods. The particle size was determined by the sieve method for $d \geq 0.063 \mathrm{~mm}$ and areometric for $\mathrm{d}<0.063 \mathrm{~mm}$ [9]. The yield stress was determined by the roller method and the Casagrande flow limit [11]. Optimal moisture content and maximum skeletal density were determined in a Proctor in a cylinder of $1.0 \mathrm{dm} 3$ at a density of $0.59 \mathrm{~J} \cdot \mathrm{cm}^{-3}[6]$.

The retention characteristics of the tested soil were also determined by means of porous plates in pressure chambers within the range of potentials $\mathrm{pF}$ from 1 to 4.2 (corresponding to the vacuum height from 1 to $15484 \mathrm{~cm}$ ). The soil samples were compacted using Proctor's standard density compaction at a humidity of approximately $1 \%$ greater than the optimum. Prior to testing, the densified samples were saturated with water for several days, and after being placed in the pressure chamber, they were dried to gradually increase the vacuum values (suction pressure). At each pressure value, the test was carried out until the sample mass stabilized, which was then converted to the volumetric moisture of the soil. The retention curves obtained from the studies are described by the van Genuchten equation [18]:

$$
\theta=\theta_{r}+\frac{\left(\theta_{s}-\theta_{r}\right)}{\left[1+\left(\alpha \cdot\left(u_{a}-u_{w}\right)\right)^{n}\right]^{\left(1-\frac{I}{n}\right)}}
$$

where:

$\theta_{r}$ - residual volume moisture, $\alpha, n$ - equation constant, , $\theta$ - volume humidity, $\theta_{\mathrm{s}}$ - volume moisture content of saturated soil, $u_{a}$ - air pressure in pores, $u_{w}-$ water pressure in pores.

Determination of shear strength parameters was carried out in a shear box with a cross-sectional dimension of $6 \times 6 \mathrm{~cm}$ and a sample height of $1.8 \mathrm{~cm}$. The test specimens were molded into a Proctor apparatus in a $1.0 \mathrm{dcm} 3$ cylinder with $0.59 \mathrm{~J} . \mathrm{cm}^{-3}$ thickening power and then cut in the appropriate mold and placed in the box of the apparatus. The tests were performed on samples concentrated at optimum humidity and greater and less than about $3 \%$ for Bochnia and less by $1 \%$ and more by almost $3 \%$ for Cracow land. In the case of samples thickened at higher humidity than the optimum test, without and with a failure of the cut surface. The shear rate was $1.0 \mathrm{~mm} \cdot \mathrm{min}^{-1}$ and allowed quick shear of soil samples, which theoretically limits the possibility of causing water pressure in the pores of the soil [17]. The 
shear strength parameters were also determined at a shear rate of $0.05 \mathrm{~mm} \cdot \mathrm{min}^{-1}$ for samples formed at optimum humidity. In these studies, the consolidation and cutting of the samples were done at failure. This type of test according to [10] makes it possible to obtain effective parameters for shear strength of the soil. Samples were consolidated with a load of $100 \mathrm{kPa}$ for 12 hours and shredded at $25,50,75,100,125$ and $150 \mathrm{kPa}$ to achieve $15 \%$ relative horizontal deformation of the sample.

Analysis of the results of the shear strength parameters was based on the degree of plasticity of the tested soil, which made it possible to compare them with the literature data. Comparative analysis of the results obtained from both shear speeds was also performed, which allowed us to determine the influence of suction forces on shear strength parameters. For the purpose of this analysis, a simplified model of shear strength of the unsaturated soil proposed by Vanapalli and others [16]:

$\tau_{f}=c^{\prime}+\left(\sigma_{n}-u_{a}\right) \cdot \tan \phi^{\prime}+\left(u_{a}-u_{w}\right) \cdot \Theta^{\kappa} \cdot \tan \phi^{\prime}$

where:

$\phi^{\prime}-$ effective internal friction angle, c' - effective cohesion of the soil, $\sigma_{\mathrm{n}}-$ normal component, $\kappa$ - equation match parameter, $\Theta$ - degree of soil saturation $\left(\theta / \theta_{\mathrm{s}}-\theta\right.$ - soil moisture content, $\theta_{\mathrm{s}}-$ volume moisture content of saturated soil), $\mathrm{u}_{\mathrm{a}}, \mathrm{u}_{\mathrm{w}}-$ as in the formula (1).

\section{Basic physical properties of the examined land}

Table 1 presents the basic geotechnical characteristics of the studied land. The soil from Bochnia was classified as sandy loam, while from Krakow it was sandy dust [8]. Both lands were dominated by a dust fraction of over $50 \%$. On the other hand, these lands differed significantly in the content of the sand fraction - in the land of Krakow, it was 1.5 times higher than in the land of Bochnia, which in turn was characterized by more than three times the content of clay. Differences in the content of the clay fraction led to Bochnia soil being characterized by higher values of consistency limits, and its yield index was nearly $11 \%$ higher than that of Krakow. The soil properties were characterized by good compaction from the point of view of their usefulness for the purposes of earth construction [12]. Higher values of maximum skeletal density and lower optimum humidity were obtained for sandy dust. The optimum moisture values obtained show that the best soil compaction has a compact state corresponding to the value of the plasticity $\mathrm{I}_{\mathrm{L}}=-0,05$ in the case of land from Bochnia and $\mathrm{I}_{\mathrm{L}}$ $=-0,35$ for land from Krakow.

Figure 1 shows the retention curves of both land. Values of the van Genuchten equation were $\alpha=0.02342 \mathrm{~m}^{-1}$ and $\mathrm{n}=1.11137$ for sandy dust $-\alpha=0.02307 \mathrm{~m}^{-1}$ and $\mathrm{n}=$ 1.19034. It was found that the values of the parameter $\alpha$ for both lands were similar and similar to the values reported in Lu and Griffiths [2004] for sandy soils, while the values of parameter $\mathrm{n}$ were in the range for clay soils [3]. The retention characteristics obtained indicate that at optimum humidity the suction pressure for sandy loam was $173 \mathrm{~cm}$ and for sand dust $261 \mathrm{~cm}$. 
a) saclSi (Bochnia)

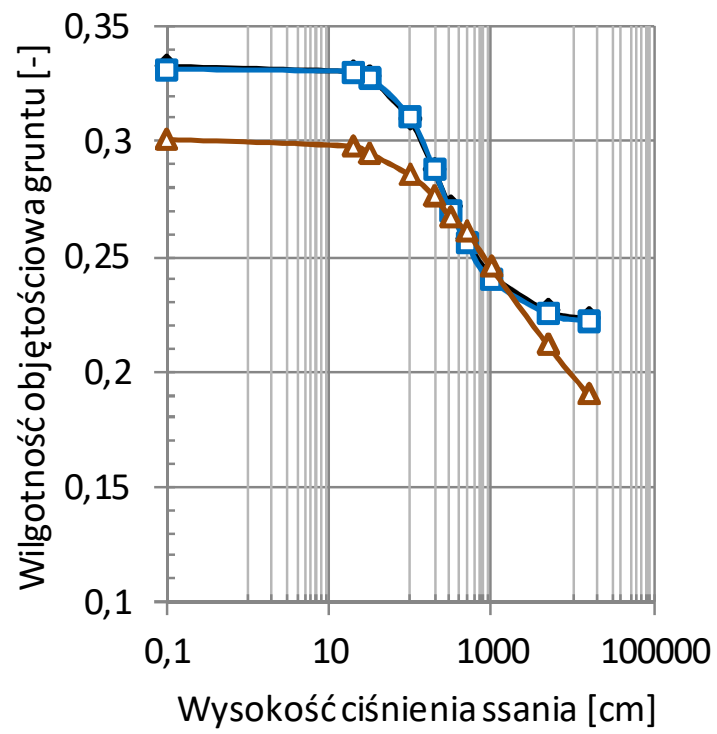

b) saSi (Kraków)

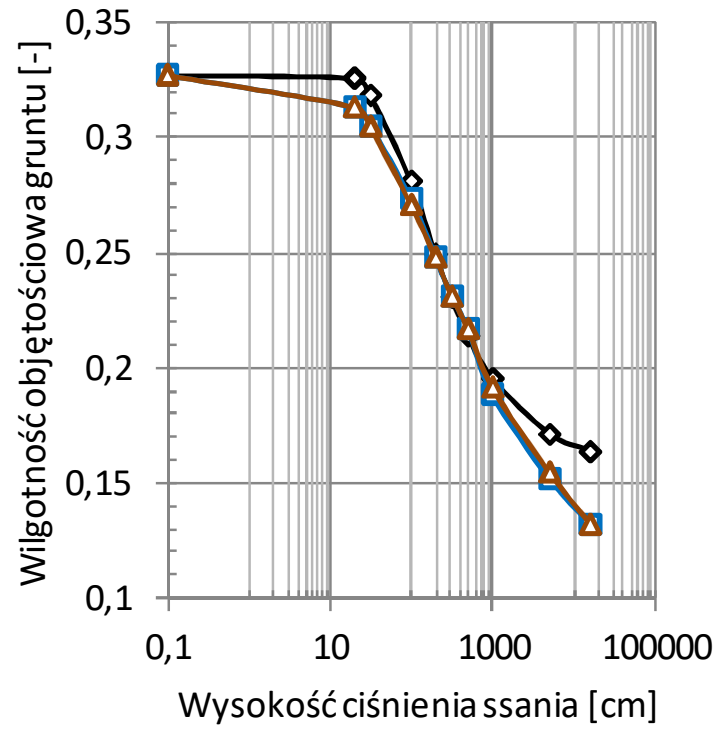

$\leadsto$ próbka $1 \rightarrow \square$ próbka $2 \rightarrow$ próbka 3

1. Retention curves of the studied lands

Tab.1. Physical properties of the examined lands

\begin{tabular}{|l|c|c|}
\hline \multicolumn{2}{|c|}{ Parameters } & \multicolumn{2}{c|}{ Origin of land } \\
\cline { 2 - 3 } & Bochnia & Krakow \\
\hline Fraction content [\%]: & & \\
- sand $(0,063-2 \mathrm{~mm}$ ), & 30,2 & 44,4 \\
- dust $(0,002-0,063 \mathrm{~mm})$, & 53,1 & 50,9 \\
- loam $(<0,002 \mathrm{~mm}$ ). & 16,7 & 4,7 \\
\hline The name of the land by PN-EN ISO 14688-2:2004 & saclSi & saSi \\
& (dust clay-sand) & (sandy dust) \\
\hline The name of the land by PN-B-02480:1986 & $\mathrm{G}$ & $\Pi_{\mathrm{p}}$ \\
& (clay) & (sandy dust) \\
\hline Optimum humidity [\%] & 16,5 & 13,1 \\
\hline optimal volume humidity [-] & 0,292 & 0,238 \\
\hline Maximum skeleton volume density [g $\left.\cdot \mathrm{cm}^{-3}\right]$ & 1,77 & 1,82 \\
\hline Porosity at maximum density [-] & 0,332 & 0,310 \\
\hline Plasticity limit [\%] & 17,1 & 14,6 \\
\hline Liquidity limit [\%] & 34,0 & 20,3 \\
\hline Plasticity index [\%] & 16,9 & 6,14 \\
\hline
\end{tabular}

\section{Research results and their analysis}

The increase of the moisture content of the compacted samples by $6 \%$ in the case of clay-sand dust caused variations in plasticity in the range of -0.24 to 0.14 , with variations in the skeletal density from 1.68 to $1.77 \mathrm{~g} \mathrm{~cm}^{-3}$ (Fig. 3a). On the other hand, for sand dust $4 \%$ increase in humidity resulted in changes in the plasticity in the range of -0.55 to 0.16 and the density of the skeleton in the range, not exceeding $0.02 \mathrm{~g} . \mathrm{cm}-3$. In the case of both lands, the highest density was achieved at optimum humidity. 
a) saclSi (Bochnia)

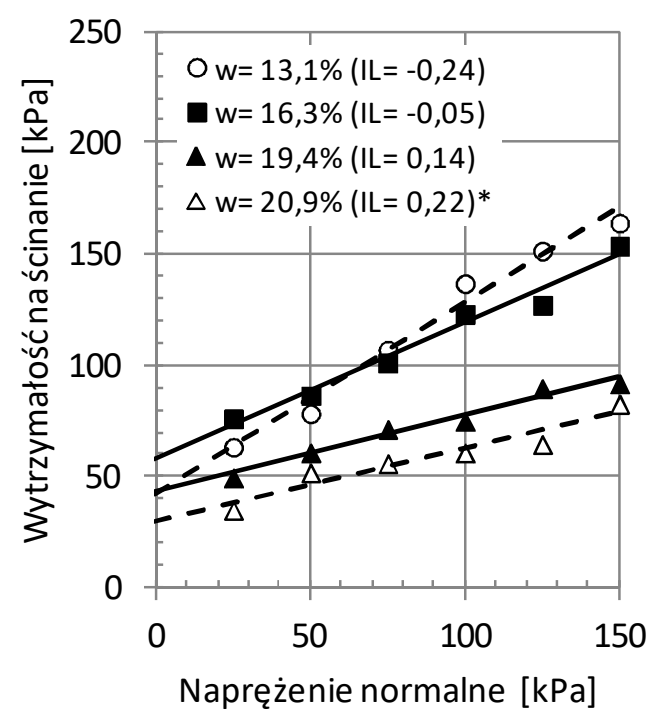

b) saSi (Kraków)

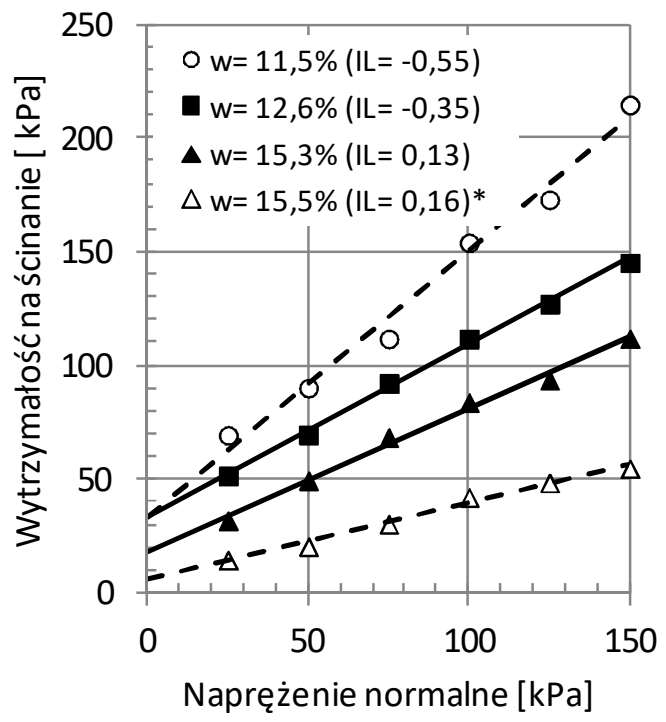

2. Shear strength of the tested soil obtained at different moisture density of samples and shear rate $1,0 \mathrm{~mm} \cdot \mathrm{min}^{-1}$ Explanation: * The samples are compacted at higher humidity than the optimum and shaved with a failure of the cut surface.

Figures 2-3 show the results of the shear strength test obtained at a shear rate of 1.0 mm.min ${ }^{-1}$. It has been found that the shear strength values of both soils have decreased with increasing their plasticity. Particularly significant changes in shear strength were obtained for sand dust, which was probably related to its low plasticity. For clay-sand dust shear strength values obtained for samples with lower and optimum humidity can be considered as close. In the case of sand dust, the highest values of shear strength were obtained for samples with lower than optimum humidity.

It should be noted that the failure of the samples to be concentrated at higher than optimum humidity slightly increased the final moisture content of the samples, but significantly reduced the shear strength of the test soil. This effect was more pronounced in the case of sand dust.

High shear strength was reflected in the values of internal friction angle and consistency of the investigated soils (Fig. 3b, c). It was found that the increase in humidity caused the reduction of the internal friction angle, as indicated by Pisarczyk [5], which is characteristic of natural mineral soil. It was noted that the obtained values of internal friction angle of the examined land were higher than those reported by Wiłun [19] and Pisarczyk [5]. However, the values of this parameter do not differ significantly from those reported in, among others, in Steckiewicz and Zabielska-Adamska [14] or in foreign literature [4], [1].

Comparing the values of internal friction angle obtained for both lands, it was found that higher values were obtained for sand dust, which was related to higher content of sand fraction. 
a)

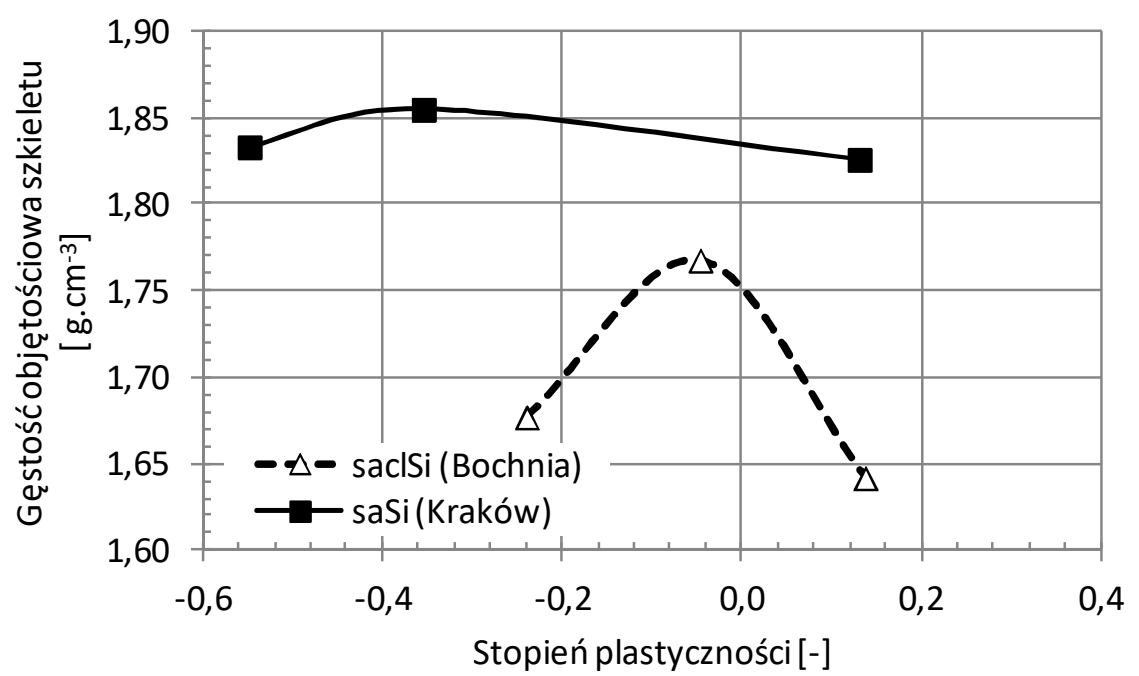

b)

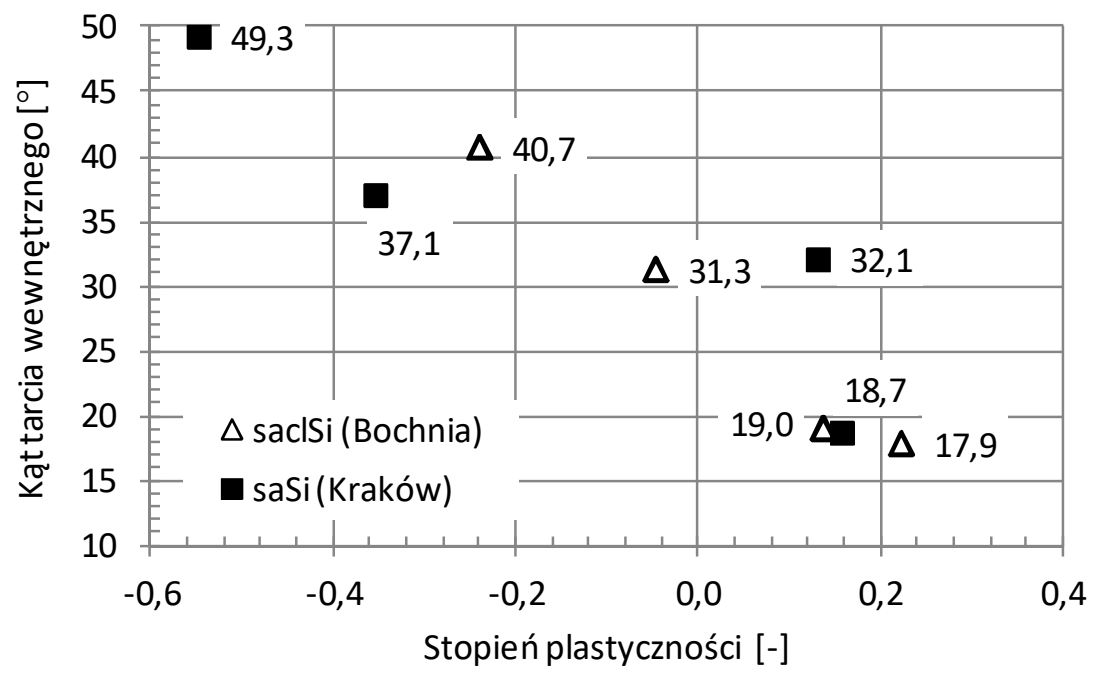

c)

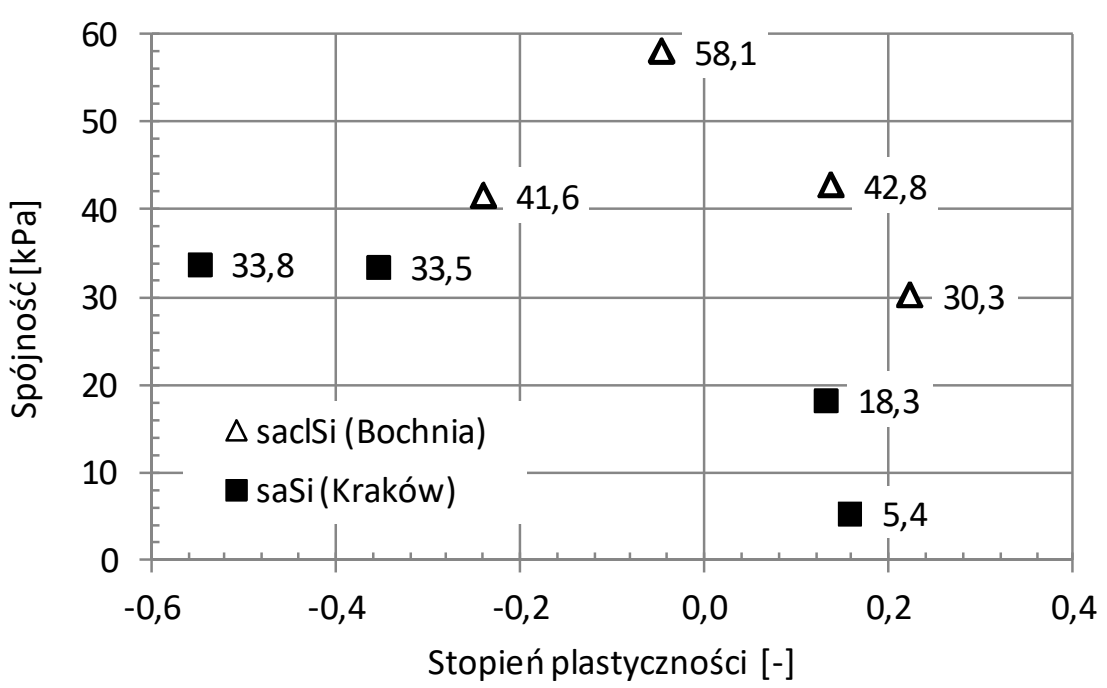

3. The dependence of the skeletal density (a), the internal friction angle (b) and the cohesion (c) on the plasticity of the examined lands 
In the case of cohesive sandy loam, the highest values were obtained with optimum humidity, which is a common connotation for natural mineral soils and due to their maximum density obtained with this humidity [5]. On the other hand, for sand dust the cohesion values obtained with optimal and lesser humidity were similar.

Comparative analysis of shear strength parameters without and with a failure of the shear surface of samples obtained at a shear rate of $1.0 \mathrm{~mm} \cdot \mathrm{min}^{-1}$ revealed the significant influence of the shear on the values obtained. In the case of clayey sand, the values of the internal friction angle and cohesion of the regression tests were respectively 42 and $30 \%$ relative to those of the unchecked test. In turn, for sand dust, the impact of failure on the obtained values of the internal friction angle was negligible, but it was clearly marked in the case of cohesion, the value obtained for samples without failure was more than 3 times higher than that of samples with failures.

The above results of shear strength without failure of the miter plane cannot be considered as universal. These results refer to the study of unsaturated soil samples in which the soil pores are partially filled with air. So they also take into account the occurrence of sucking in the ground, which increases the shear strength of the soil. Therefore, shear strength tests have been performed in accordance with PKN-CEN ISO / TS 17892-10: 2009 [10], which recommends that the consolidation and shear process is carried out under ground conditions and the shear rate should be determined on the basis of the consolidation process. These treatments aim at mapping shear conditions corresponding to the occurrence of effective stresses.

The tests carried out at a shear rate of $0.05 \mathrm{~mm} \cdot \mathrm{min}^{-1}$ (Fig. 4) showed that in the case of clayey sand, the values of internal friction angle and cohesion were $31.6^{\circ}$ and $17.2 \mathrm{kPa}$, respectively. In the case of sand dust, the value of internal friction angle was $34.8^{\circ}$ and cohesion $2.0 \mathrm{kPa}$.

The values of the internal friction angle obtained for both land were significantly higher than the value of this parameter given for small and medium salinity by Włomun [19]. However, the values of effective internal friction angles for Smoltczyk's low and medium plasticity [13]. On the other hand, the angle of friction of the sandy loam was similar to the effective value of this parameter obtained by Krysiak et al. [2] for castings with similar grain size to the sandy loam. By analyzing the values of cohesion of both land, it was found that they were smaller than those reported by Wiłun [19] but could be considered as close to the cohesion values given in Sun and Xu [15] and Wysokiński [20]. 
a) saclSi (Bochnia)

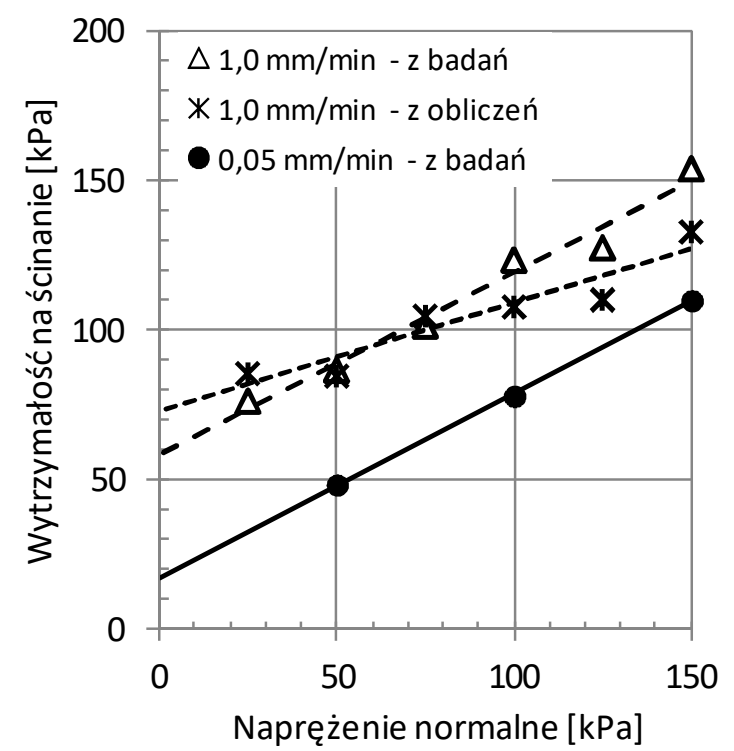

b) saSi (Kraków)

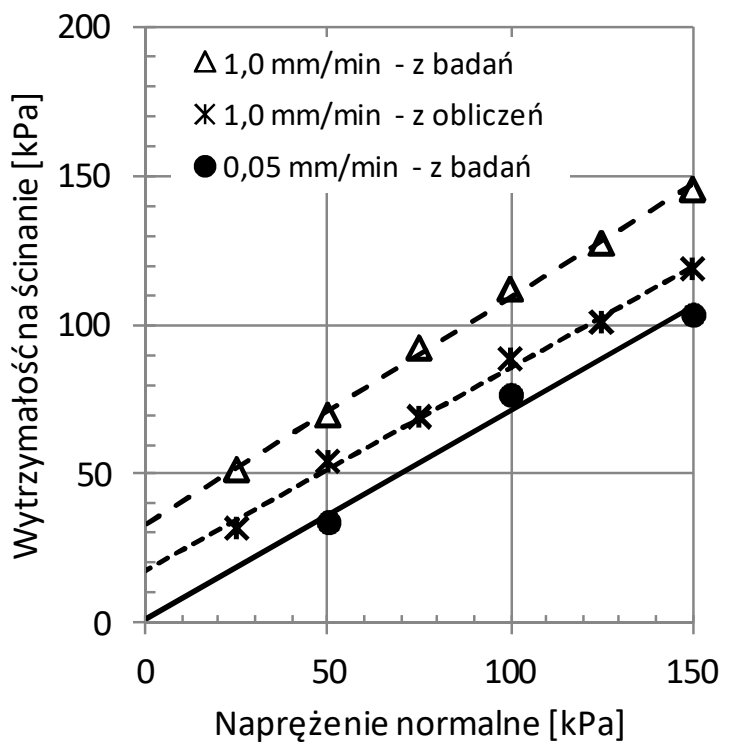

4. Line of shear strength of tested soil obtained from tests and calculations with optimal humidity and both shear rates

Comparison of the results from the compacted samples at optimum and shear moisture at 0.05 and $1.0 \mathrm{~mm} \cdot \mathrm{min}^{-1}$ (Fig. 4) indicates that the use of lower shear rate and lowering of samples results in a slight degree of internal friction angle. has a very significant impact on cohesion. From the point of view of estimating the stability of earth constructions, the parameters obtained from the tests at a lower shear rate appear to be more secure.

Using the relationship (1) and (2) the theoretical shear strength of shear samples at optimum humidity and velocity $1.0 \mathrm{~mm} \cdot \mathrm{min}^{-1}$ was determined. It was found that the theoretical values of shear strength were lower than the values obtained from the tests, which may be due to the use of an approximate method of estimating the suction pressure present in the examined soil. It should also be noted that the retention characteristics shown above take into account the results obtained for samples formed at higher relative humidity than the optimum, thus having a slightly higher porosity than the samples formed at optimum humidity. The discrepancies between the results of the tests and the calculations may also be due to the application of high shear rate, which may favor the phenomenon of grafting of thicker grains, as demonstrated by other authors' work. [21].

\section{Conclusions}

1. The studied lands were characterized by different values of shear strength parameters, which significantly influenced the humidity.

2. The most advantageous values of shear strength parameters were achieved at optimal humidity or slightly lower than optimum. The results showed that as the soil moisture increased, the values of internal friction angle decreased and in the case of cohesion the highest values were obtained with optimum humidity.

3. It has been shown that soil failure during consolidation and shear has a reduced shear strength, which results in a reduction of the cohesion value.

4. The obtained results show that the investigated soils are characterized by high values of internal friction angle and cohesion at optimum humidity, which makes it possible to determine their suitability for the construction of earth embankments. As indicated by the research, in order to maintain the high shear strength of the tested land, they should be protected from access to infiltration and groundwater. 


\section{Source materials}

[1] Bonsch C., Lempp C. Shear Strength Affected by Suction Tension in Unsaturated Fine Grained Soils? [W:] Schanz T. (Ed.) Experimental Unsaturated Soil Mechanics. Springer, 145-152, 2007.

[2] Krysiak S., Sahajdak K., Skutnik Z., Zajdel J. Dobór parametrów podłoża do projektowania zabezpieczenia wykopu na podstawie wyników pomiaru sił w kotwach. Acta Scientiarum Polonorum Architectura, 15(3), 55-70, 2016.

[3] Lu N., Griffiths D.V. Profiles of steady-state suction stress in unsaturated soils. Journal of Geotechnical and Geoinvironmental Engineering, 130, 10, 1063-1076, 2004.

[4] Matsushi Y., Matsukura Y. Cohesion of unsaturated residual soils as a function of volumetric water content. Bull Eng Geol Env 65: 449-455, 2006.

[5] Pisarczyk S. Grunty nasypowe. Właściwości geotechniczne i metody ich badania. Oficyna Wyd. Politechniki Warszawskiej, 2004.

[6] PN-B-04481:1988. Grunty budowlane. Badania próbek gruntu. Polski Komitet Norm Miar i Jakości, Warszawa

[7] PN-B-12095:1997. Urządzenia wodno-melioracyjne. Nasypy. Wymagania i badania przy odbiorze. Polski Komitet Normalizacyjny, Warszawa.

[8] PN-EN ISO 14688-2:2004. Badania geotechniczne. Oznaczenie i klasyfikacja gruntów. Część 2. Zasady klasyfikowania. Polski Komitet Normalizacji, Warszawa.

[9] PKN-CEN ISO/TS 17892:2009. Badania geotechniczne, Badania laboratoryjne gruntów, Część 4: Oznaczanie składu granulometrycznego, Polski Komitet Normalizacyjny, Warszawa,

[10] PKN-CEN ISO/TS 17892-10:2009. Badania geotechniczne. Badania laboratoryjne gruntów. Część 10. Badanie w aparacie bezpośredniego ścinania. Polski Komitet Normalizacyjny, Warszawa.

[11] PKN-CEN ISO/TS 17892-12:2009. Badania geotechniczne, Badania laboratoryjne gruntów, Część 12: Oznaczanie granic Atterberga, Polski Komitet Normalizacyjny, Warszawa.

[12] PN-S-02205: 1998. Drogi samochodowe. Roboty ziemne. Wymagania i badania. PKN, Warszawa.

[13] Smoltczyk U. Geotechnical Engineering Handbook. Volume 1: Fundamentals. Ernst \& Sohn, 2002.

[14] Steckiewicz R., Zabielska-Adamska K. Określenie wytrzymałości gruntów w polowym aparacie bezpośredniego ścinania. XI Krajowa Konferencja Mechaniki Gruntów i Fundamentowania, 25-27 czerwca 1997, Gdańsk, 151-154. 1997.

[15] Sun S., Xu H. Determining the shear strength of unsaturated silt. [W:] Schanz T. (Ed.) Experimental Unsaturated Soil Mechanics. Springer, 195-206, 2007.

[16] Vanapalli S.K., Fredlund D.G., Pufahl D.E, Clifton A.W. Model for prediction of shear strength with respect to soil suction. Canadian Geotechnical Journal, 33: 379392, 1996.

[17] Vanapalli S.K., Lane J.J. A simple technique for determining the shear strength of fine-grained unsaturated soils using the conventional direct shear apparatus. Proceedings of the Second Canadian Specialty Conference on Computer Applications in Geotechnique, Winnipeg, 245-253, 2002.

[18] van Genuchten M.T. A closed form equation for predicting the hydraulic conductivity of unsaturated soils. Soil Science Society American Journal, 44, 892-898, 1980.

[19] Wiłun Z. Zarys geotechniki. WKit, 2003. 
[20] Wysokiński L. Ocena stateczności skarp i zboczy. Instytut Techniki Budowlanej, Instrukcje, Wytyczne, Poradniki, Nr 424/2006. 36.

[21]Zydroń T., Kogut M., Gruchot A. Wpływ prędkości ścinania na kształtowanie się parametrów wytrzymałościowych gruntów $\mathrm{z}$ obszaru karpackiego. Górnictwo $\mathrm{i}$ Geoinżynieria, 35 (2), 619-626, 2011. 